\title{
SME Internationalization in Emerging Markets: Symbiotic vs. Commensal Pathways
}

\author{
Andrey Mikhailitchenko \\ California State University, Sacramento \\ 6000 J. St., Sacramento, 95819-6088, CA, USA \\ Sanjay Varshney \\ California State University, Sacramento \\ 6000 J. St., Sacramento, 95819-6088, CA, USA
}

Received: 28 February 2015 / Revised: 20 March 2016 / Accepted: 2 April 2015 / Published online: 6 May 2016

\begin{abstract}
Purpose - The purpose of this research is to develop, test, and validate the symbiotic networking concept of SMEs internationalization pathways.

Design/Methodology/Approach - Survey data were collected from managers/owners of SMEs operating in the textile industry in China and Russia. The applied data analysis technique employed is structural equation modeling. The survey was pretested to address reliability, validity, and cross-cultural stability issues.

Findings - The symbiotic networking relationships in SMEs were shown to be positively related to their degree of internationalization. The relationship between networking and internationalization is significantly stronger in the conditions of high rather than low environmental turbulence.

Research Limitations/Implications - Further research should validate the findings in other industries and other countries. Future research may also include in the model other cultural, attitudinal, environmental, and managerial variables, as well as other dependent variables, first of all from consumer behavior and marketing communications fields.

Practical Implications - The findings may assist in identifying networking clusters of SMEs in emerging economies that are more likely to enter foreign markets and develop more targeted support and educational programs aimed at facilitating the internationalization of small businesses. The research results also assist in the elaboration of managerial tools in multinational entrepreneurial businesses.

Originality/Value - The research contributes to the field by empirically investigating, testing, and putting into a unified framework the measurement tools required for identifying the symbiotic networking interactions of SMEs and the influence of these interactions on SME internationalization pathways.
\end{abstract}

JEL classification: C300, F230, M160, P200, O430

Keywords: international business, structural equation model, entrepreneurship, China, Russia 


\section{INTRODUCTION}

Small and medium enterprises (SMEs) are playing an increasing role in the global marketplace, especially in emerging markets, and their internationalization pathways are the subject of increasing research interest. It is widely recognized that the networking of SMEs is one of the crucially important factors in their internationalization process (Coviello and Munro, 1997; Jones, 1999). With the widely accepted view of networking as one of the powerful institutional and environmental factors pushing SMEs towards global market, there is an increasing demand for research investigating specific networking pathways and their antecedents and outcomes in terms of SMEs' internationalization (Zhou et al., 2007; Mejri and Umemoto, 2010).

As a theoretical framework, social capital theory provides insight into networking as a process that increases SMEs' resources and enhances their competitiveness in the international market (Chetty and Agndal, 2007; Partanen et al., 2008). One of the characteristics of social capital is that it may be firm- and action-specific (Griffith and Harvey, 2004). Being a facilitator of certain activities, it may be useless or even harmful for others (Coleman, 1988). As pointed out by Tang (2011, p. 201), "There is still limited research on understanding networking behaviors that precede and precondition network outcomes."

In a broader sense, this study is a response to calls for studying the sources and outcomes of networking in SMEs' activities and internationalization, in particular, in emerging and transitional economies (Zhou and Xin, 2003; Senik et al., 2011). More specifically, the research question this study pursues to address is as follows: What factors are influencing the networking pathways of SMEs' internationalization and conditioning their outcomes?

In the current research we use the "input-pathway-output" chain framework. By input we understand the type of managerial style prevalent in a SME, by pathway the type of collaborative networking at the stage of internationalization in which a SME is involved, and by output we mean the different dimensions of the degree of internationalization of a firm (DOI).

In this current study we are making an attempt to advance the research in the direction of building an integrative and predictive framework of relationships between SMEs' networking and internationalization pathways. In earlier studies, research on this topic was generally qualitative in nature (Coviello and Munro, 1997; Zain and Ng, 2006; Amal and Filho, 2009; Chetty and Stangl, 2010), with some recent exceptions (Tang, 2011; Kamakura et al., 2012). This study employs quantitative analysis and is intended as a step towards a testable and operationalizable model of SME internationalization pathways.

In terms of geographic scope, SME internationalization literature is enriched by the substantial body of recent research investigating networking perspective of SME internationalization in developed countries such as the UK (Hutchinson et al., 2006), New Zealand (Chetty and Stangl, 2010), Finland (Kontinen and Ojala, 2011), Australia (Freeman et al., 2006), Sweden (Osarenkhoe, 2010), and Spain (Ramos et al., 2011) as well as emerging economies such as China (Tang, 2011), Malaysia (Zain and Ng, 2006), Singapore (Dana et al., 2009), Korea (Lee et al., 2012), and India (Javalgi et al., 2011).

The evident gap in SME internationalization research is the sector of transition economies such as Russia and CIS countries. Overall, to the best of our knowledge, there are no studies in SME networking and internationalization fields that are based on a cross-cultural sample of firms from countries representing developed, emerging, and transition economies. In our study, we are attempting to fill the gap by including SMEs from China and Russia. 


\section{LITERATURE REVIEW, THEORY DEVELOPMENT AND HYPOTHESES}

\subsection{Networking perspective of SME internationalization}

The importance of networking perspective in SME internationalization research is widely recognized in the extant literature (Johanson and Mattsson, 1988; Malhotra et al., 2003). Social capital theory provides a view on networking as a factor compensating for the lack of resources that SMEs own or control (Coviello and Cox, 2006). Extant research demonstrates that major resources and capabilities provided by networks are information and market intelligence (Mejri and Umemoto, 2010), experiential knowledge and guidance to decision making (Fuller-Love and Thomas, 2004), managerial expertise (Zain and Ng, 2006), innovation capability (Möller et al., 2005), and ability to overcome size inconveniencies and reduce the risks (Coviello and McAuley, 1999).

In SMEs in which management is in much higher degree based on the subjective and relationship-based components than in large scale enterprises, networking becomes a powerful factor influencing strategic decisions, including the decision to internationalize (Johanson and Mattsson, 1988). This influence is exercised through the exchange of resources between network members and absorption of ideas generated due to network relationships (Wincent, 2005). The institutional relationships in the networks not only play a role of triggers and motivators of internationalization, but also influence the entry modes (Blomstermo et al., 2006), product development selections (Coviello and Munro, 1997), choice of markets and distribution channels (Hogg et al., 2003), and patterns and pathways of internationalization (Senik et al., 2011).

\subsection{Networking typology}

The literature on SME internationalization demonstrates that not only the degree of network involvement of firms, but also the type and nature of their networking relationships are crucial for understanding their internationalization process (Chetty and Campbell-Hunt, 2003). Different components of networking may have a different, sometimes opposite, impact on SMEs' various business activities, including internationalization (Witt, 2004); therefore productive research of SME internationalization pathways is hardly possible without having an insight into networks typology.

The recent literature offers several classification schemes, depending on the criteria serving as a base for the classification (Street and Cameron, 2007). Heracleous and Murray (2001) propose a taxonomy of five network types (edge of chaos, embedded, brokered, atomistic, and association networks) based on the dimensions of interdependence and durability. Xie and Johnston (2004) draw a distinction between operational cooperation networks and strategic alliances, based on dimensions of scope and intensity. Möller et al. (2005) identified different types of strategic business networks using the capability-based analysis. Johnston et al. (2006) propose a multi-dimensional networks classification framework including such criteria as reinforcement, complementarity, synergy, and reciprocity. Castells (2009) delineates between horizontal and vertical networks, depending on the type of prevailing intermarket linkages that they provide.

\subsection{Symbiotic type of networking}

In this study we use the network typology initially proposed by Astley and Formbrun (1983) that was integrated into the strategy literature by Dollinger (1990), Dollinger and Golden (1992), and Golden and Dollinger (1993) and then gave rise to a stream of studies in SME networking area (Alexander, 1998; Dana et al., 2000; Rao, 2002; Botti and Torres, 2008; Tsai and Lai, 2010). The major component of this typology is a distinction between symbiotic and non-symbiotic (commensal, commensalistic) networks. 
The major criteria of networks classification along the non-symbiotic (commensal) vs. symbiotic continuum is whether network creation and development is based on pursuing direct economic or indirect economic (or sometimes completely non-economic) goals (Astley and Formbrun, 1983). According to Crenshaw et al. (2000, p. 376), "Symbiotic unions are defined by complementary exchange relationships ... Commensal unions, on the other hand, are based on the similarity of members." The example of a symbiotic network in the textile industry may be a set of family-owned SMEs supporting each other by sharing costs and risks and specializing in different business processes, such as importing yarn from abroad, producing knitted fabrics, manufacturing ready-made garments, advertising, transportation, or sales. An example of a nonsymbiotic (commensal) network may be a regional textile federation, including fabrics and textiles manufacturers, wholesalers, and retailers.

Symbiotic network members do not compete with each other while internetwork competition is typical for non-symbiotic (commensal) ones. According to Etemad et al. (2001, p. 481), "In a truly symbiotic relationship, neither party can compete effectively without the continued contribution of the other." Respectively, interfirm level joint activities (such as joint advertising, joint research, etc.) with suppliers or buyers are common in symbiotic and absent in non-symbiotic (commensal) networks (Golden and Dollinger, 1993). There are, however, some other, less evident delineation criteria. All of the criteria are summarized in Table 1, based on the characteristics presented by Astley and Formbrun (1983), Golden and Dollinger (1993), Crenshaw et al. (2000), and Etemad et al. (2001).

Table 1

Characteristics of Networks on a Symbiotic-Non-symbiotic (Commensal) Contin

\begin{tabular}{|c|c|c|}
\hline Criteria & Symbiotic & $\begin{array}{l}\text { Non-symbiotic (commensal, } \\
\text { commensalistic) }\end{array}$ \\
\hline Networking motivation & Mostly relationship-based & Primarily function-based \\
\hline Membership formality & Often informal (“"netizenship”) & $\begin{array}{l}\text { Mostly formal, with articulated set } \\
\text { of mutual obligations }\end{array}$ \\
\hline $\begin{array}{l}\text { Interdependence of network } \\
\text { members }\end{array}$ & $\begin{array}{l}\text { As a rule, strong; exit barriers are } \\
\text { high }\end{array}$ & $\begin{array}{l}\text { Not necessarily strong; } \\
\text { relationships can often be easily } \\
\text { terminated }\end{array}$ \\
\hline Role of networks & Social \& business & Purely business \\
\hline $\begin{array}{l}\text { Joint firm-level activities within } \\
\text { network }\end{array}$ & $\begin{array}{l}\text { Presence of joint advertising, joint } \\
\text { research etc. }\end{array}$ & $\begin{array}{l}\text { No firm-level joint activities, only } \\
\text { network-level ones }\end{array}$ \\
\hline $\begin{array}{l}\text { Presence of competition between } \\
\text { network members }\end{array}$ & $\begin{array}{l}\text { Members do not compete with each } \\
\text { other }\end{array}$ & $\begin{array}{l}\text { Members often do compete with } \\
\text { each other }\end{array}$ \\
\hline Internal culture & Embeddedness is emphasized & Autonomy is emphasized \\
\hline Knowledge \& information flows & Implicit in high degree & Mostly explicit \\
\hline Type of communication & $\begin{array}{l}\text { Face-to-face communication } \\
\text { prevails }\end{array}$ & $\begin{array}{l}\text { Non-personal communication } \\
\text { prevails }\end{array}$ \\
\hline
\end{tabular}

\subsection{Symbiotic networking and SME internationalization pathways}

Senik et al. (2011) reported three major sources of networking: personal contacts, business associates, and institutions. In SMEs in which networking activity is carried out predominantly by the owner-manager, the role of personal networks is extremely important (Gilmore et al., 2006). Personal contacts are the major component of symbiotic type relationships and a source of social capital for SMEs (Pinho, 2011). 
In emerging and transition economies, symbiotic ties play an especially important role due to the fact that institutional mechanisms of supporting small businesses (such as government agencies, small and medium business supporting bodies, etc.) and business associates (chambers of commerce, industrial federations, etc.) are not well established or do not play a substantial role in small business everyday operations (Bruton et al., 2008). The corruption in state organizations and imperfect legal and judicial systems also facilitate development of symbiotic networking relationships. Not only in emerging and transitional economies, but also in mature developed economies, symbiotic networking may play an important role in groups of enterprises (e.g., ethnic family businesses) in which businesses help each other in many ways, such as with ideas, technology, competence, and capital (Gäre and Melin, 2011).

SMEs base their internationalization decision on limited external marketing information (Freeman et al., 2006). Therefore, this increases the role of such factors as positive word of mouth about foreign market opportunities and moral influence of other network members who are already internationalized (Street and Cameron, 2007). The symbiotic network in this case plays the role of a communication avenue for non-rational, subjective, and personal relationship based motives for internationalization, in addition to the calculative ones that are communicated both by symbiotic and non-symbiotic (commensal) networks (Etemad, 2004). This communication feature of symbiotic networks is conditioned by the prevailing non-formal relationship pattern and network members' mutual reliance on each other in a sustained, ongoing manner, in contrast to non-symbiotic (commensal) ones (Golden and Dollinger, 1993; Etemad et al., 2001).

Based on the above discussion, we hypothesize the following:

$\mathrm{H}_{1}$ : SMEs' involvement in symbiotic networks is positively related to their degree of internationalization.

\subsection{Management styles and type of SME networking}

As conceptualized by Purcell (1987), management style refers to the choices made and the underlying rationale for the way in which management treats its employees. It is defined as a "distinctive set of guiding principles, written or otherwise, which set parameters to and signposts for management action in the way employees are treated and particular events handled" (p. 535). The conceptually co-sounding definition of management style proposed by Rodriguez (2005) states that it "refers to the way traditional managerial functions of controlling, planning, communication, decision-making, motivation, and control are carried out in organizations" (p. 78). Management style is considered to be determined by a set of factors such as the strategic orientation of a firm (Merz et al., 1994), institutional forces (Lee et al., 2000), and cultural values (Poon et al., 2005).

Cross-cultural research in the field, as stated by Culpan and Kucukemiroglu (1993), requires clearly defined domains or properties of a management system to use as a basis of comparison. Culpan and Kucukemiroglu (1993) proposed a set of fundamental dimensions of management systems that include participative supervision (the degree of manager's participation in subordinate's routine work flow), paternalistic orientation (the extent to which the supervisor participates in employees' non-work related matters), and information sharing (the degree of key information accessibility to employees and the rate of information flow within the company).

The choice of the above mentioned dimensions for the current study is dictated first of all by their relevance for exploring the link between management style and networking (Redding, 1995; Haley, 1997; Griffith et al., 2006). The major theory providing the grounds for this link is the production, distribution, and rule-making systems model (hereafter, identified as the PDR systems model) (Lee, 1996). Based on this theory, the intra- and interorganizational relationships are connected to each other in a logical, real-world framework. 
The PDR model-based concept of "inward" and "outward" management (O'Toole et al., 2005) holds that managerial culture inside a firm (supervisory, decision-making, etc.) is tightly connected with its outward management (i.e., the way it builds networking relationships with other companies). Within this framework, management media (employees, subordinates, etc.) and outer media (partners, suppliers, etc.) are considered parts of one business network in which a firm is involved; thus, the norms and traditions of inward management media are transferred to outward management. As pointed out by Hakansson (2006), the within-company organization is a prerequisite for between-companies interorganizational relationships (IOR).

\subsection{Management style dimensions and symbiotic networking}

Participative supervision is a part of family-like managerial style in a company (Mavondo and Rodrigo, 2001). In SMEs, especially in emerging economies, very often it means absence of contractual employment regulations, and, as a consequence, adherence to non-contractual network in the relationship with networking business partners (Pheng and Leong, 2000). On the interorganizational relationship level, it leads to quasi-family interorganizational ties in which mutual obligations of network members are not documentarily articulated and legally fixed. These relationships are characterized by strong familiar ties that make replacement of network members difficult and create higher entrance and exit barriers (Moorhead and Griffin, 1995) that are attributes of symbiotic networks. Based on the above discussion, the following hypothesis is proposed:

$\mathrm{H}_{2}$ : A supervising manager's participation in subordinates' routine work

flow in a SME is positively related to a predisposition to the symbiotic type

of interorganizational networking.

A high degree of paternalism, from a human resources perspective, is a part of a company philosophy based on concern for employee needs and cooperation. The paternalistic approach is an attribute of relationship-motivated rather than task-motivated leadership (Lee, 2001). The same approach, applied to cross-organizational relationships, results in non-formalized, nonhierarchical IORs that are inherent in symbiotic networks (Culpan and Kucukemiroglu, 1993). Thus, based on the above discussion, the following hypothesis is stated.

$\mathrm{H}_{3}$ : The paternalistic orientation of SME managers is positively related to a

predisposition to symbiotic type of interorganizational networking.

The within-company information sharing style is also tightly linked to IOR strategies. The free information flow is the result of management strategy predisposed to intensive socialization (Ouchi, 1981). Unlike formal communication, the informal or grapevine form of communication occurs when information flows freely and rumors are allowed to flourish (Schermerhorn and Nyaw, 1992). In interorganizational relationships, this attitude results in the presence of nonwritten and non-verbal communication links, which play an important role in networks. This communication pattern also leads to non-business related links, relationships that are not dictated by immediate economic profit, and higher interdependence of network members (Robbins et al., 1994) (i.e., those relationships that are a characteristic feature of symbiotic rather than nonsymbiotic (commensal) networks); therefore, the next hypothesis is as follows:

$\mathrm{H}_{4}$ : The higher within-SME information flow is positively related to

a predisposition to symbiotic type of interorganizational networking.

\section{RESEARCH MODEL}

The proposed model is based on the integration of two research paths - the research on SME internationalization within the marketing discipline and the research on business networking 
within the management discipline. It continues the emerging stream of cross-disciplinary research on small business globalization (e.g., Coviello and Munro, 1997; Coviello and McAuley, 1999; McDougall and Oviatt, 2000). The research model is shown in Figure 1.

Figure 1

Research model

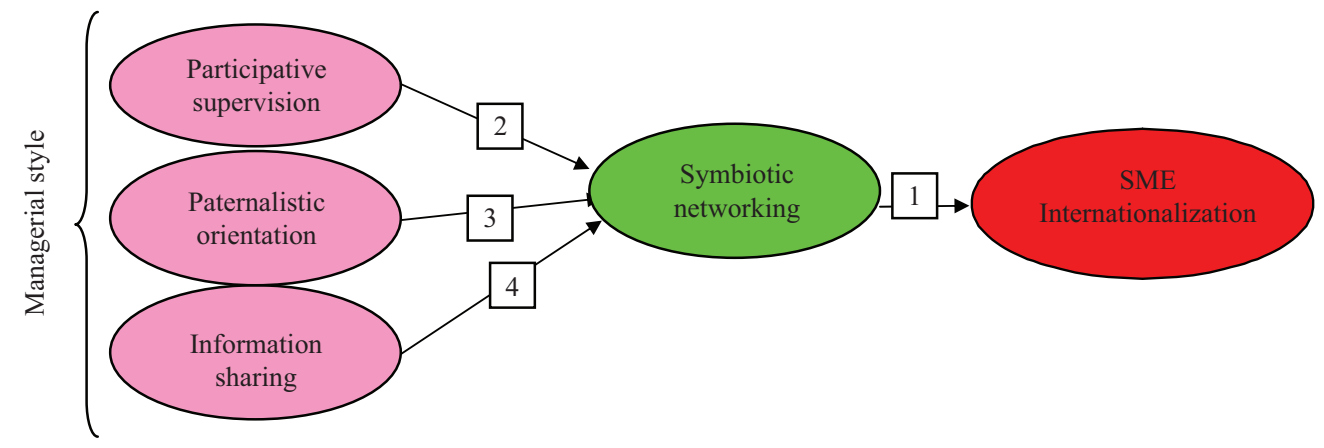

Sampling. We chose compatible sample frames from the two countries participating in the research (China and Russia): for China - the national list of domestic manufacturers issued by the China Chamber of Commerce for Import and Export of Textiles (17565 firms), and for Russia - the list of RosTextile Concern Fair Members (1621 firms). Our choice of an industry-wide homogeneous sample was made based on the rationale of keeping control over the "industry" variable. A systematic random sample was drawn on an nth name basis from each of these databases to provide a stratified sample of the textile industry's SMEs in China and Russia. We contacted the respondents with the web surveying tool. The translation and back translation of the questionnaire was employed for achieving conceptual equivalence (Douglas and Craig, 2007).

If no response rate improving techniques were applied, the expected response rate, based on results of the studies on industrial online surveys, should range from $25 \%$ to $45 \%$ (Bowling et al., 2006). Therefore, we used such techniques as the presence of an invitation postcard, Web design letting a respondent see only one page of a survey at a time, a guarantee of anonymity, a statement that respondents will not be contacted again with ads, and a follow-up letter or phone call. Because the research team included people fluent in three languages (English, Chinese, and Russian) the follow-up phone calls were found to be an effective tool, especially in the case of China. As a result, the total sample of 531 firms was obtained (287 and 244 for Russia and China, respectively). The final response rate was 40.5 percent. This level of response fits the indicators given in the literature related to online surveying (Porter and Whitcomb, 2007).

Measurement. The degree of internationalization (DOI) was measured with Sullivan's (1994) methodology as a composite of five ratios related to different aspects of a firm's international activities, such as (1) foreign sales and (2) foreign assets as a percentage of total sales and assets, respectively, (3) overseas partners percentage, (4) cumulative duration of firm managers' international assignments weighted by their work experience, and (5) the dispersion of the firm's operations among the ten psychic zones of the world. A scale for symbiotic networking introduced by Golden and Dollinger (1993) and employed in the networking literature (MacGregor, 2004; Gilmore et al., 2006) contains the list of interorganizational activities that reflects a company's involvement in different types of symbiotic networking: joint research and advertising with partners, suppliers or customers; membership in community, social, political or religious organizations. The management style related constructs were measured based on the work of Albaum and Herche (1999), and Poon et al. (2005).

We initially pretested all scales on a smaller sample that included 42 firms from two countries and employed the EFA to determine whether the obtained scales fit the dimensionality of constructs. Based on the results of the pretest, those items that did not demonstrate satisfactory 
loading patterns were eliminated. The cutoff for significant factor loadings was 0.4 and factors were kept based, first, on the dimensionality of the constructs and, second, on the explained variance (Deng and Dart, 1994). All factors were rotated using the varimax procedure.

Structural Equation Model. The collected data were analyzed using the structural equation modeling (SEM). The hypothesized model is shown in Figure 2.

Figure 2

Structural equation model

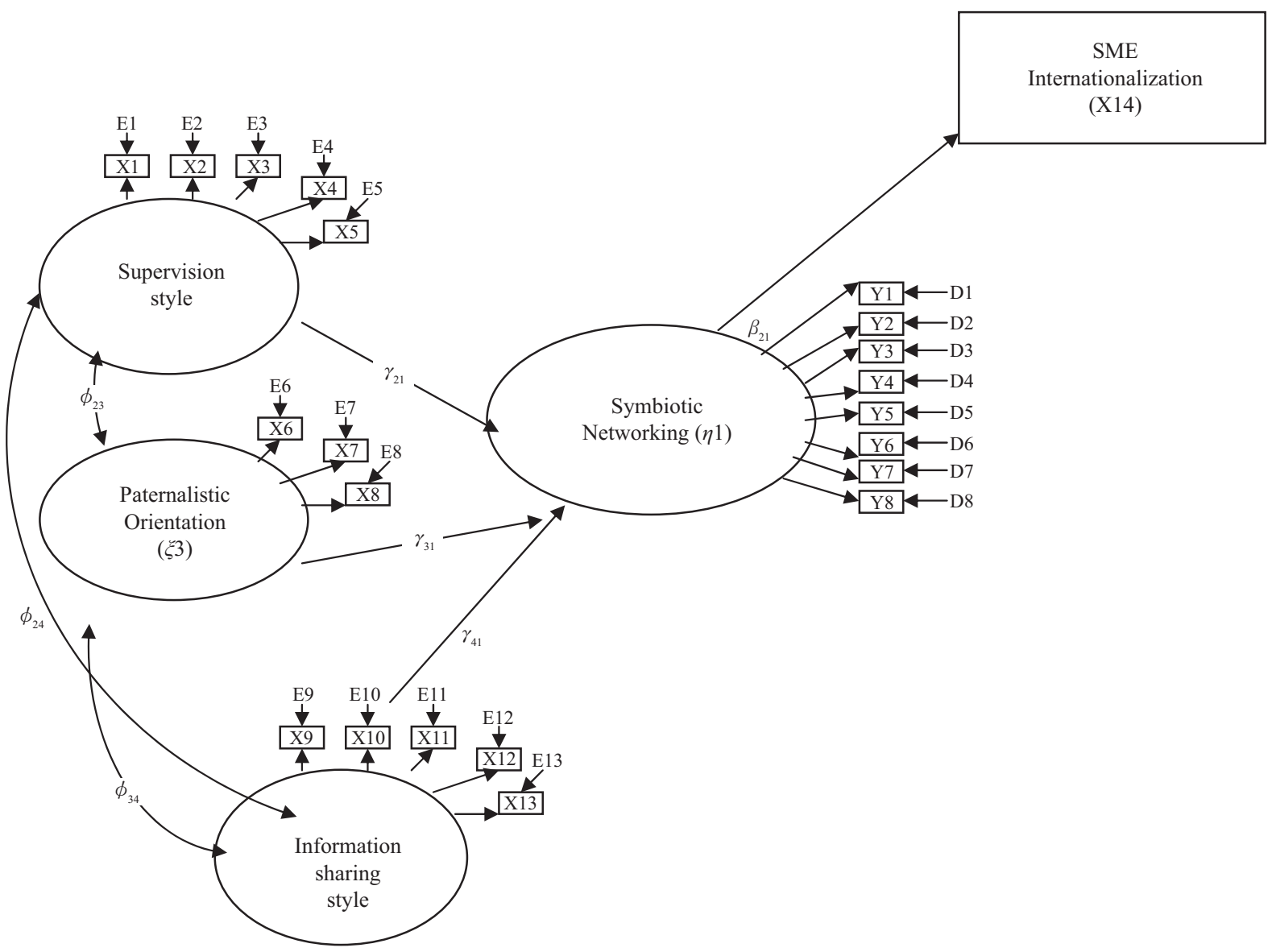

Reliability, Validity, and Cross-Cultural Stability. In the main study, we assessed the stability of the final measures again. In addition to calculating the Cronbach alpha coefficient, we assessed Fornell and Larcker's (1981) composite reliabilities, which were all above the threshold value of 0.70 . The factor loadings were all positive and significant, providing evidence of convergent validity (Table 2). 
Table 2

Reliability and Validity Indicators in Cross-Cultural Setting

\begin{tabular}{|c|c|c|}
\hline Scale & Chinese sample & Russian sample \\
\hline \multicolumn{3}{|l|}{ Symbiotic Networking } \\
\hline Cronbach's & .935 & .935 \\
\hline \multicolumn{3}{|l|}{ Factor loadings of items: } \\
\hline SYMBIOTIC_NETWORKING 1 & .936 & .873 \\
\hline SYMBIOTIC_NETWORKING 2 & .917 & .848 \\
\hline SYMBIOTIC_NETWORKING 3 & .871 & .854 \\
\hline SYMBIOTIC_NETWORKING 4 & .931 & .890 \\
\hline \multicolumn{3}{|l|}{ Participative Supervision } \\
\hline Cronbach alpha & .727 & .722 \\
\hline \multicolumn{3}{|l|}{ Factor loadings of items: } \\
\hline SUPERVISION 1 & .720 & .669 \\
\hline SUPERVISION 2 & .668 & .666 \\
\hline SUPERVISION 3 & .674 & .612 \\
\hline SUPERVISION 4 & .755 & .727 \\
\hline SUPERVISION 5 & .576 & .641 \\
\hline \multicolumn{3}{|l|}{ Paternalistic Orientation } \\
\hline Cronbach alpha & .558 & .550 \\
\hline \multicolumn{3}{|l|}{ Factor loadings of items: } \\
\hline PATERNALISM 1 & .634 & .590 \\
\hline PATERNALISM 2 & .767 & .767 \\
\hline PATERNALISM 3 & .731 & .753 \\
\hline \multicolumn{3}{|l|}{ Information Sharing } \\
\hline Cronbach alpha & .879 & .816 \\
\hline \multicolumn{3}{|l|}{ Factor loadings of items: } \\
\hline INFORMATION_SHARING 1 & .875 & .741 \\
\hline INFORMATION_SHARING 2 & .797 & .707 \\
\hline INFORMATION_SHARING 3 & .785 & .633 \\
\hline INFORMATION_SHARING 4 & .837 & .744 \\
\hline INFORMATION_SHARING 5 & .780 & .656 \\
\hline
\end{tabular}

We performed the initial assessment of cross-cultural stability by running the EFA on two datasets separately - the Chinese and Russian samples respectively. Then, the extent to which reliability and validity indicators were invariant across these three samples was examined.

Then, we followed Steenkamp and Baumgartner's (1998) procedure for assessing configural and metric invariance of measure. The multiple group analysis involved two groups of observations in the Chinese and Russian subsamples. The systematic model comparison included the chi-square difference test between the unconstrained model, configural invariance model (with one item per construct loading fixed to one, and its intercept fixed to zero for each group), and full metric invariance model (with all loadings constrained to be equal across groups). 
Model Fit Indicators. To test the hypothesized model shown in Figure 2 we conducted maximum likelihood structural equation modeling with AMOS 18. The evaluation with the goodness of fit procedure was performed. The model fits well: $\chi_{(390)}{ }^{2}=527.66(p<.01)$, $\chi^{2} / d f=1.353$; the comparative fit index $(\mathrm{CFI})=.984$, recommended $\geq .90$ (Bentler, 1990); the root mean square error of approximation $(\mathrm{RMSEA})=.021$, recommended $\leq .05$ (Browne and Cudeck, 1993); Tucker and Lewis index $(\mathrm{TLI})=.982$, recommended $\geq .90$ (Tucker and Lewis, 1973); normalized fit index $(\mathrm{NFI})=.942$, recommended $\geq .90$ (Bentler and Bonnet, 1980); incremental fit index $(\mathrm{IFI})=.98$, recommended $\geq .90($ Bentler, 1990).

\section{RESULTS}

$\mathrm{H}_{1}$ states that symbiotic network relationships are positively related to a SME's degree of internationalization. The SEM results $\left(\beta_{12}=.182, \mathrm{p}<.000\right)$ provide support for it. As an additional testing procedure we performed a multiple paired comparisons tests for differences across the groups. The whole sample was subdivided into 3 groups with high (DOI score 2.70 and higher), medium (DOI score between 2.3 and 2.6) and low (DOI score 2.2 and lower) degrees of internationalization. The ANOVA followed by Tukey's HSD and Scheffe's post-hoc tests demonstrated the significantly higher symbiotic networking score of SMEs on higher levels of internationalization. In all cases the difference of means was significant at the .01 level, providing the additional support for $\mathrm{H}_{1}$.

We found support for $\mathrm{H}_{2}$ as well, which postulated a positive relationship between participative type of supervision in a company and the symbiotic networking pattern $\left(\gamma_{31}=.447, p<.000\right)$. The higher degree of paternalism in managerial style $\left(\mathrm{H}_{3}\right)$ was shown to influence the predisposition to symbiotic rather than commensal relationships as well $\left(\gamma_{41}=.676, \mathrm{p}<.000\right)$. More free information flow within a company $\left(\mathrm{H}_{4}\right)$ is also a driver of symbiotic IORs $\left(\gamma_{51}=.440, \mathrm{p}<.000\right)$ (Table 3$)$.

Table 3

SEM Regression Estimates

\begin{tabular}{|c|c|c|}
\hline & \multicolumn{2}{|c|}{ SYMBIOTIC_NETWORKING ${ }^{\mathrm{x}}\left(\eta_{1}\right)$} \\
\hline SUPERVISION $\left(\xi_{2}\right) \rightarrow$ & $.447(.034)$ & $\mathrm{p}<.000$ \\
\hline $\operatorname{PATERNALISM~}\left(\xi_{3}\right) \rightarrow$ & $.676(.121)$ & $\mathrm{p}<.000$ \\
\hline INFORMATION_SHARING $\left(\xi_{4}\right) \rightarrow$ & $.440(.049)$ & $\mathrm{p}<.000$ \\
\hline $\mathrm{DOI}^{\mathrm{z}} \leftarrow$ & $.182(.011)$ & $\mathrm{p}<.000$ \\
\hline
\end{tabular}

${ }^{\mathrm{x}}$ Latent endogenous variable

${ }^{\mathrm{y}}$ Latent exogenous variables

${ }^{\text {a }}$ Numbers in parentheses are standard errors

${ }^{\mathrm{b}}$ Arrow denotes direction of causation

${ }^{\mathrm{z}}$ Manifest endogenous variable

To summarize, the results suggest that relationship-driven model of within-company managerial style results in symbiotic between-SMEs relationships which, in turn, lead to a "leapfrogging" internationalization pace characterized by higher resource commitment starting right from the initial stage. In contrast, function-based managerial style predisposes SMEs to non-symbiotic (commensal) IORs that facilitate more gradual and stepwise internationalization (Figure 3). 
Figure 3

Conceptual Overview of Results

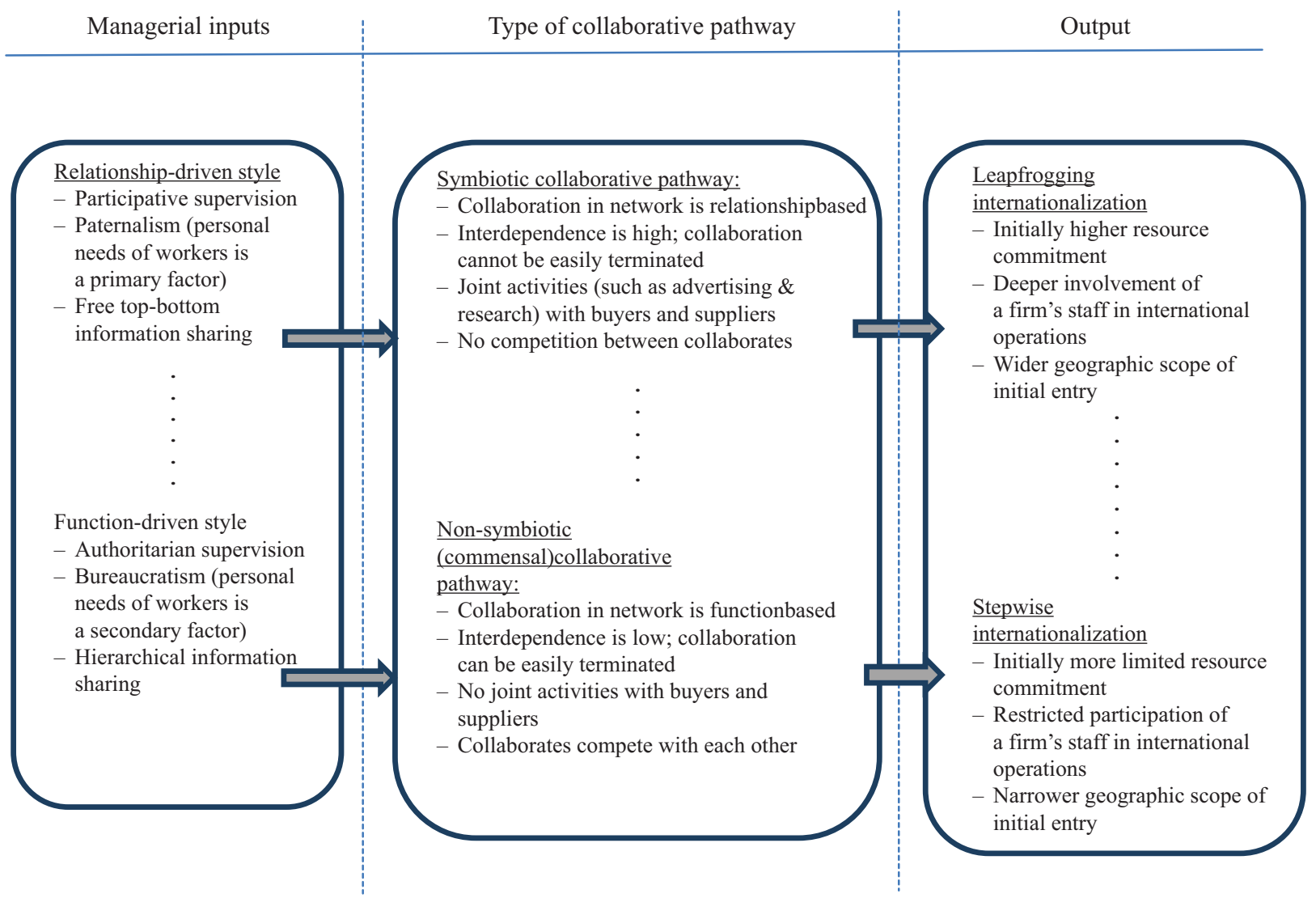

\section{CONCLUSION AND IMPLICATIONS}

Theoretical Contribution. The theoretical contribution of the study can be characterized as extending the frameworks of networking perspective of SME internationalization. The study is a step towards classification and conceptualization of factors underlying the typology of networking strategies and internationalization pathways of SMEs. It provides insight into how different types of IOR networking (symbiotic vs. commensal) influence SME internationalization.

The constructs reflecting the typology of SMEs' networking activities as well as its managerial and environmental antecedents were measured and operationalized. In this way, the study makes an advancement towards overcoming the traditional criticism of the networking theory, which is that it does not provide a predictive and testable framework that could explain SMEs' internationalization.

Another contribution of the study to the field is that it tested the proposed model on a diversified sample recruited from two emerging economies that are very distinct from each other in terms of culture, business, legal, political environment, history, and traditions: China and Russia. Employing this diversified sample contributed to supporting the credibility of the proposed model and allowed the stability of the constructs' measures in a cross-cultural setting to be tested.

Managerial/Practical Relevance of the Study. The research findings may be of interest to four major groups of stakeholders. First are governmental organizations that execute policies and regulations related to domestic small businesses. An understanding of the networking mechanisms of SME internationalization can assist governmental organizations to execute targeted programs of small business support.

Another group of stakeholders that could benefit from the results of this study comprises international organizations. The study findings provide them with knowledge needed for 
elaborating and carrying out international networking programs for small and medium enterprises. It especially refers to those international organizations and multinational structures that act within the Asia-Pacific framework (which includes China and Russia), such as the Asia-Pacific Economic Cooperation (APEC).

The results of the study would be of interest to educational institutions, especially those business colleges and schools in emerging economies that have Executive MBA programs in entrepreneurship and international business areas. Understanding the networking factors leading to different types of interorganizational relationships and different SME internationalization pathways as well as their antecedents helps to develop educational and training programs designed for owners and managers of those enterprises that are entering world markets.

Finally, the findings may assist small and medium businesses themselves. The theoretical comprehension of a networking perspective of internationalization provides guidance in the area of building network relationships aimed at the fulfillment of an enterprise's business goals on global markets. SME executives may strategically plan the intended internationalization steps based on diagnosing their current position in terms of the type of network involvement and turbulence of their business environments.

Study Limitations and Future Research Directions. Like any other international study, this one has certain limitations that must be recognized and discussed. The sample is homogeneous in terms of the industry (fabrics, garments, and accessories production and distribution). The research results can be considered generalizable only after performing studies that validate the findings in other industries. Two industrial cluster samples, which can be used for future research, are knowledge-based industries and service industries.

Future research agendas may also include the investigation of the influence of additional cultural, attitudinal, environmental, and managerial variables conditioning different types of networking and respectively pathways of SME's internationalization. The research should be expanded to include other dependent variables, first of all those that are related to consumer behavior and marketing communications fields. A broader array of countries representing emerging markets should be included in the scope of research as well.

\section{References}

Albaum, G. and Herche, J. (1999) "Management Style Comparisons Among Five European Nations", Journal of Global Marketing, Vol. 12 No. 4, pp. 5-27.

Alexander, E.R. (1998). “A Structuration Theory of Interorganizational Coordination: Cases in Environmental Management”, International Journal of Organizational Analysis, Vol. 6 No. 4, pp. 334-55.

Amal, M. and Filho, A.R. (2009) "Internationalization of Small and Medium-Sized Enterprises: A Multi Case Study", European Business Review, Vol. 22 No. 6, pp. 608-23.

Astley, W.G. and Fombrun, C.F. (1983). "Collective Strategy: Social Ecology of Organizational Environments", Academy of Management Review, Vol. 8 No. 4, pp. 576-87.

Bensaou, M., and Venkatraman, N. (1995) "Configurations of Interorganizational Relationships: A Comparison between U.S. and Japanese Automakers", Management Science, Vol. 41, pp. 1471-92.

Bentler, P.M. (1990) “Comparative Fit Indexes in Structural Equation Modeling”, Psychological Bulletin, Vol. 107 No. 2, pp. 238-46.

Bentler, P.M. and Bonnett, D.G. (1980) "Significance Tests and Goodness of Fit in the Analysis of Covariance Structures”, Psychological Bulletin, Vol. 88 No. 3, pp. 588-606.

Blomstermo, A., Sharma, D., and Sallis, J. (2006) "Choice of foreign market entry mode in service firms", International Marketing Review, Vol. 23 No. 2, pp. 211-229.

Botti, L. and Torres, O. (2008) "Small Businesses and Top-Down Tourism Collective Strategies: The Proximity Management Approach Contribution”, in: International Council for Small Business (ICSB) World Conference Proceedings, Washington, DC.

Bowling, M., Rimer, B.K., Lyons, E.J., Golin, C.E., Frydman, G., and Ribisl, K.M. (2006) "Methodological challenges of e-health research", Evaluation \& Program Planning, Vol. 29 No. 4, pp. 390-396. 
Browne, M.W. and Cudeck, R. (1993) “Alternative Ways of Assessing Model Fit”, in: Bollen, K.A. and Long, J.S. (Eds.), Testing Structural Equation Models, Newbury Park, CA: Sage.

Bruton, G.D., Ahlstrom, D., and Obloj, K. (2008) "Entrepreneurship in Emerging Economies: Where Are We Today and Where Should the Research Go in the Future", Entrepreneurship Theory and Practice, Vol. 32 No. 1, pp. $1-14$.

Burton, L., Lauridsen, J., and Obel, B. (2002) "Return on Assets Loss from Situational and Contingency Misfits", Management Science, Vol. 48 No. 11, pp. 1461-85.

Cadogan, J. (2010) "Comparative, cross-cultural, and cross-national research: A comment on good and bad practice", International Marketing Review, Vol. 27 No. 6, pp. 601-05.

Carney, M.G. (1987) “The strategy and structure of collective action”, Organization Studies, Vol. 8 No. 4, pp. $341-62$.

Castells, M. (2009) The Rise of the Network Society, $2^{\text {nd }}$ ed., Wiley-Blackwell: Hoboken, NJ.

Chao, M. C.-H. and Spillan, J.E. (2010) "The journey from market orientation to firm performance: A comparative study of US and Taiwanese SMEs", Management Research Review, Vol. 33, Iss. 5, pp. 472-84.

Chetty, S. and Campbell-Hunt, C. (2003) "Paths to Internationalization among Small- to Medium-Sized Firms. A Global versus Regional Approach”, European Journal of Marketing, Vol. 37 No. 5/6, pp. 796-820.

Chetty, S. and Agndal, H. (2007) "Social Capital and Its Influence on Changes in Internationalization Mode Among Small and Medium-Sized Enterprises”, Journal of International Marketing, Vol. 15 No. 1, pp. 1-29.

Chetty, S.K. and Stangl, L.M. (2010) "Internationalization and innovation in a network relationship context", European Journal of Marketing, Vol. 44 No. 11/12, pp. 1725-1743.

Coleman, J.S. (1988) "Social Capital in the Creation of Human Capital”, The American Journal of Sociology, Vol. 94, pp. $95-121$.

Coviello, N.E. and McAuley, A. (1999) "Internationalization and the Smaller Firm: A Review of Contemporary Empirical Research", Management International Review, Vol. 39 No. 3, pp. 223-256.

Coviello, N.E. and Munro, H.J. (1997) "Network Relationships and the Internationalization Process of Small Software Firms”, International Business Review, Vol. 6 No. 4, pp. 361-86.

Coviello, N.E. and Cox, M.P. (2006) "The resource dynamics of international new venture networks", Journal of International Entrepreneurship, Vol. 4 No. 2-3, pp. 113-132.

Crenshaw, E.M., Christenson, M., and Oakey, D.R. (2000) "Demographic Transition in Ecological Focus", American Sociological Review, Vol. 65 No. 3, p. 371-391.

Culpan, R. and Kucukemiroglu, O. (1993) “A Comparison of U.S. and Japanese Management Styles and Unit Effectiveness", Management International Review, Vol. 33 No. 1, pp. 27-42.

Dana, L.-P., Etemad, H., and Wright, R. (2000) “The Global Reach of Symbiotic Networks", Journal of Euromarketing, Vol. 9 No. 2, pp. 1-16.

Dana, L., Hamilton, R., and Wick, K. (2009) "Deciding to export: An exploratory study of Singaporean entrepreneurs", Journal of International Entrepreneurship, Vol. 7 No. 2, pp. 79-87.

de Mooij, M. (1998) Global Marketing and Advertising: Understanding cultural paradoxes. Thousand Oaks, CA: Sage Publications, Inc.

Deng, S. and Dart, J. (1994) "Measuring Market Orientation: A Multi-factor, Multi-item Approach", Journal of Marketing Management, Vol. 10 No. 8, pp. 725-742.

Dollinger, M.J. and Golden, P.A. (1992) "Interorganizational and Collective Strategies in Small Firms: Environmental Effects and Performance", Journal of Management, Vol. 18 No. 4, pp. 695-716.

Dollinger, M.J. (1990) “The Evolution of Collective Strategy of a Positive Reputation”, Academy of Management Review, Vol. 15, pp. 266-85.

Douglas, S.P. and Craig, C.S. (2007) “Collaborative and Iterative Translation: An Alternative Approach to Back Translation”, Journal of International Marketing, Vol. 15 No. 1, pp. 30-43.

Earley, P.C. (1994) "Self or group? Cultural effects of training on self-efficacy and performance", Administrative Science Quarterly, Vol. 39 No. 1, p. 89.

Etemad H., Wright R.W., and Dana, L.P. (2001) "Symbiotic international business networks: collaboration between small and large firms", Thunderbird International Business Review, Vol. 43, pp. 481-499.

Etemad, H. (2004) "International Entrepreneurship as a Dynamic Adaptive System: Towards a Grounded Theory", Journal of International Entrepreneurship: Special Issue on International Entrepreneurship, Vol. 2 No. 1-2, pp. 5-59.

Fornell, C. and Larcker, D.F. (1981) "Evaluating Structural Equation Models with Unobservable Variables and Measurement Error", Journal of Marketing Research, Vol. 18, February, pp. 39-50.

Frazier, B.J. and Niehm, L.S. (2004) "Exploring Business Information Networks of Small Retailers in Rural Communities", Journal of Developmental Entrepreneurship, Vol. 9 No. 1, pp. 23-42.

Freeman, S., Edwards, R., and Schroder, B. (2006) "How Smaller Born-Global Firms Use Networks and Alliances to Overcome Constraints to Rapid Internationalization”, Journal of International Marketing, Vol. 14 No. 3 , pp. 33-63. 
Fuller-Love, N. and Thomas, E. (2004) "Networks in small manufacturing firms", Journal of Small Business and Enterprise Development, Vol. 11 No. 2, pp. 244-253.

Gäre, K. and Melin, U. (2011) "SMEs need formative infrastructure for business transformation", Journal of Enterprise Information Management, Vol. 24 No. 6, pp. 520-533.

Gilmore, A., Carson, D., Grant, K., O’Donnell, A., Laney, R., and Pickett, B. (2006) "Networking in SMEs: Findings from Australia and England", Irish Marketing Review, Vol. 18 No. 1/2, pp. 21-28.

Golden, P.A. and Dollinger, M.J. (1993) "Cooperative alliances and competitive strategies in small manufacturing firms”, Entrepreneurship: Theory and Practice, Vol. 4, pp. 43-5.

Griffith, D.A., Myers, M.B., and Harvey, M.G. (2006) “An Investigation of National Culture's Influence on Relationship and Knowledge Resources in Interorganizational Relationships Between Japan and the United States", Journal of International Marketing, Vol. 14 No. 3, pp. 1-32.

Griffith, D.A. and Harvey, M.G. (2004) "The influence of individual and firm level social capital of marketing managers in a firm's global network", Journal of World Business, Vol. 39 No. 3, pp. 244-254.

Håkansson, H. (2006) "Business Relationships and Networks: Consequences for Economic Policy”, Antitrust Bulletin, Vol. 51 No. 1, pp. 143-63.

Haley, G.T. (1997) “A strategic perspective on overseas Chinese networks’ decision-making”, Management Decision, Vol. 35 No. 7/8, pp. 587-95.

Hatvany, N. and Pucik, V. (1981) “An Integrated Management System: Lessons from the Japanese Experience”, Academy of Management Review, Vol. 6 No. 3, pp. 469-80.

Heracleous, L. and Murry, J. (2001) "Networks, interlocking directors and strategy: Toward a theoretical framework", Asia Pacific Journal of Management, Vol. 18 No. 2, pp. 137-160.

Hofstede, G. (1980) Culture's Consequences: International Differences in Work-Related Values. Beverly Hills, CA: Sage Publications.

Hogg, S., Medway, D., and Warnaby, G. (2003) "Business improvement districts: An opportunity for SME retailing”, International Journal of Retail and Distribution Management, Vol. 31 No. 8/9, pp. 466-469.

Holmlund, M. and Kock, S. (1998) "Relationships and the internationalisation of Finnish small and medium-sized companies", International Small Business Journal, Vol. 16 No. 4, pp. 46-63.

Hutchinson, K., Quinn, B., and Alexander, N. (2006) "The role of management characteristics in the internationalisation of SMEs: Evidence from the UK retail sector", Journal of Small Business and Enterprise Development, Vol. 13 No. 4, pp. 513-534.

Jaccard, J.C. and Wan, K. (1996) LISREL Approaches to Interaction Effects in Multiple Regression. Thousand Oaks, CA: Sage Publications.

Javalgi, R.G., Todd, P., and Granot, E. (2011) "The internationalization of Indian SMEs in B-to-B markets", The Journal of Business \& Industrial Marketing, Vol. 26 No. 7, pp. 542-548.

Johanson, J. and Mattsson, L.-G. (1988) "Internationalization in industrial systems - a network approach", in: N. Hood and J-E. Vahlne (Eds.), Strategies in Global Competition. New York, NY: Croom Helm.

Johanson, J. and Vahlne, J. (2011) "Markets as networks: implications for strategy-making", Journal of the Academy of Marketing Science, Vol. 39 No. 4, pp. 484-491.

Johnston, W.J., Peters, L.D., and Gassenheimer, J. (2006) “Questions about network dynamics: Characteristics, structures, and interactions”, Journal of Business Research, Vol. 59 No. 8, pp. 945-954.

Jones, M.V. (1999) “The Internationalization of Small High-Technology Firms”, Journal of International Marketing, Vol. 7 No. 4, pp. 15-41.

Jöreskog, K. and Sörbom, D. (1988) LISREL 7: A Guide to the Program and Applications. Chicago, IL: SPSS.

Kamakura, W., Ramón-Jerónimo, M., and Vecino Gravel, J. (2012) "A dynamic perspective to the internationalization of small-medium enterprises", Journal of the Academy of Marketing Science, Vol. 40 No. 2, pp. $236-251$.

Kontinen, T. and Ojala, A. (2011) "Network Ties in the International Opportunity Recognition of Family SMEs", International Business Review, Vol. 20 No. 4, pp. 440-453.

Lee, H.S. (1996) “The Interaction of Production, Distribution, and Rule-Making Systems in Industrial Relations", Relations Industrielles/Industrial Relations, Vol. 51 No. 2, pp. 302-32.

Lee, H.S. (2001) "Paternalistic Human Resource Practices: Their Emergence and Characteristics", Journal of Economic Issues, Vol. 35 No. 4, pp. 841-70.

Lee, H.S., Kelley, D., Lee, J., and Lee, S. (2012) "SME Survival: The Impact of Internationalization, Technology, Resources, and Alliances”, Journal of Small Business Management, Vol. 50 No. 1, pp. 1-19.

Lee, J., Roehl, T.W., and Choe, S. (2000) "What makes management style similar and distinct across borders? Growth, experience and culture in Korean and Japanese firms", Journal of International Business Studies, Vol. 31 No. 4, pp. 631-652.

MacGregor, R.C. (2004) "The Role of Strategic Alliances in the Ongoing Use of Electronic Commerce Technology in Regional Small Business", Journal of Electronic Commerce in Organizations, Vol. 2 No. 1, pp. 1-14.

Malhotra, N.K., Agarwal, J., and Ulgado F.M. (2003) "Internationalization and entry modes: A multitheoretical framework and research propositions”, Journal of International Marketing, Vol. 11 (December), pp. 1-31. 
Mavondo, F.T. and Rodrigo, E.M. (2001) "The Effect of Relationship Dimensions on Interpersonal and Interorganizational Commitment in Organizations Conducting Business Between Australia and China”, Journal of Business Research, Vol. 52 No. 2, pp. 111-21.

McDougall, P.P. and Oviatt, B.M. (2000) "International entrepreneurship: The intersection of two research paths", Academy of Management Journal, Vol. 43, pp. 902-08.

Mejri, K. and Umemoto, K. (2010) "Small- and medium-sized enterprise internationalization: Towards the knowledge-based model", Journal of International Entrepreneurship, Vol. 8 No. 2, pp. 156-167.

Merz, G.R., Weber, P.B., and Laetz, V.B. (1994) "Linking small business management with entrepreneurial growth", Journal of Small Business Management, Vol. 32 No. 4, pp. 48-61.

Möller, K., Rajala, A., and Svahn, S. (2005) "Strategic business nets - their type and management", Journal of Business Research, Vol. 58 No. 9, pp. 1274-84.

Moorhead, G. and Griffin, R.W. (1995) Organizational Behaviour: Managing people and organizations, 4th Edition. Boston: Houghton Mifflin Company.

Nakata, C. and Sivakumar, K. (2001) "Instituting the Marketing Concept in a Multinational Setting: The Role of National Culture", Journal of the Academy of Marketing Science, Vol. 29 No. 3, pp. 255-75.

O’Toole, L.J., Meier, K.J., and Nicholson-Crotty, S. (2005) "Managing Upward, Downward and Outward", Public Management Review, Vol. 7 No. 1, pp. 45-68.

Osarenkhoe, A. (2010) “A coopetition strategy - a study of inter-firm dynamics between competition and cooperation", Business Strategy Series, Vol. 11 No. 6.

Ouchi, William G. (1981) Theory Z. Reading, MA.: Addison Wesley.

Parnell, M.F. (2005) "Chinese business guanxi: an organization or non-organization?", Journal of Organizational Transformation \& Social Change, Vol. 2 No. 1, pp. 29-47.

Partanen, J., Möller, K., Westerlund, M., Rajala, R., and Rajala, A. (2008) "Social capital in the growth of scienceand-technology-based SMEs", Industrial Marketing Management, Vol. 37 No. 5, pp. 513-525.

Pheng, L.S. and Leong, C.Y. (2000) "Cross-cultural project management for international construction in China", International Journal of Project Management, Vol. 18 No. 5, pp. 307-17.

Pinho, J.C. (2011) "Social capital and dynamic capabilities in international performance of SMEs", Journal of Strategy and Management, Vol. 4 No. 4, pp. 404-418.

Poon, P.S., Evangelista, F.U., and Albaum, G. (2005) "A comparative study of the management styles of marketing managers in Australia and the People's Republic of China”, International Marketing Review, Vol. 22 No. 1, pp. 34-47.

Porter, S.R. and Whitcomb, M.E. (2007) "Mixed-Mode Contacts in Web Surveys", Public Opinion Quarterly, Vol. 71 No. 4, pp. 635-648.

Prashantham, S. (2005) "Toward a Knowledge-Based Conceptualization of Internationalization", Journal of International Entrepreneurship, Vol. 3, pp. 37-52.

Purcell, J. (1987) “Mapping Management Styles in Employee Relations”, The Journal of Management Studies, Vol. 24 No. 5, pp. 533-549.

Ramos, E., Acedo, F., and Gonzalez, M. (2011) "Internationalisation speed and technological patterns: A panel data study on Spanish SMEs", Technovation, Vol. 31 No. 10/11, pp. 560-572.

Rao, H. (2002) “Interorganizational ecology”, in: Baum, J.A.C. (Ed.), Companion to Organizations, Blackwell, Oxford, UK, pp. 541-556.

Redding, G. (1995) "Overseas Chinese Networks: Understanding the Enigma”, Long Range Planning, Vol. 28 No. 1, pp. 61-69.

Robbins, S.P., Waters-Marsh, T., Cacioppe, R., and Millett, B. (1994) Organizational Behavior: Australia and New Zealand. Sydney: Prentice Hall.

Rodríguez, C.M. (2005) "Emergence of a third culture: shared leadership in international strategic alliances", International Marketing Review, Vol. 22 No. 1, pp. 67-95.

Schermerhorn, J. Jr. and Nyaw, M.K. (1992) "Managerial Leadership in Chinese Industrial Enterprises", Organisation and Management in China (1979-1990), Vol. 9 No. 21.

Senik, C.Z., Scott-ladd, B., Entrekin, L., and Adham, K. (2011) "Networking and internationalization of SMEs in emerging economies”, Journal of International Entrepreneurship, Vol. 9 No. 4, pp. 259-281.

Steenkamp, J.-B. and Baumgartner, H (1998) "Assessing Measurement Invariance in Cross-National Consumer Research”, Journal of Consumer Research, Vol. 25 Issue 1, pp. 78-90.

Street, K. and Cameron, A.-F. (2007) "External Relationships and the Small Business: A Review of Small Business Alliance and Network Research”, Journal of Small Business Management, Vol. 45 No. 2; pp. 239-267.

Sullivan, D. (1994) "Measuring the degree of internationalization of a firm", Journal of International Business Studies, Vol. 25 No. 2, pp. 325-342.

Tang, Y.K. (2011) "The Influence of networking on the internationalization of SMEs: Evidence from internationalized Chinese firms", International Small Business Journal, Vol. 29 No. 4, pp. 374-398. 
Tsai, W. and Lai, Y. (2010) "Strategic Implications from Complexity Science Perspective”, Journal of Global Business Management, Vol. 6 No. 2, pp. 1-10.

Tucker, L.R. and Lewis, C. (1973) "A Reliability Coefficient for Maximum Likelihood Factor Analysis", Psychometrika, Vol. 38 No. 1, pp. 1-10.

Varamaki, E. and Vesalainen, J. (2003) "Modeling different types of multilateral co-operation between SMEs", Entrepreneurship and Regional Development, Vol. 15 No. 1, pp. 27-48.

Westhead, P., Wright, M., and Ucbasaran, D. (2004) "Internationalization of private firms: environmental turbulence and organizational strategies and resources”, Entrepreneurship and Regional Development, Vol. 16 No. 6 , pp. 501-22.

Wincent, J. (2005) "How Do Firms in Strategic SME Networks Build Competitiveness?", Journal of Enterprising Culture, Vol. 13 No. 4, pp. 383-408.

Witt, P. (2004) “Entrepreneurs' networks and the success of start-ups", Entrepreneurship \& Regional Development, Vol. 16, pp. 391-412.

Witt, P., Schroeter, A. and Merz, C. (2008) "Entrepreneurial resource acquisition via personal networks: an empirical study of German start-ups", Service Industries Journal, Vol. 28 No 7/8, pp. 953-71.

Xie, F.T. and Johnston, W.J. (2004) "Strategic alliances: incorporating the impact of e-business technological innovations", The Journal of Business \& Industrial Marketing, Vol. 19 No. 3, pp. 208-222.

Zain, M. and Ng, S.I. (2006) "The impacts of network relationships on SMEs' internationalization process", Thunderbird International Business Review, Vol. 48 No. 2, pp. 183-205.

Zhou, L., Wu, W.-P., and Luo, X. (2007) "Internationalization and the performance of born-global SMEs: the mediating role of social networks”, Journal of International Business Studies, Vol. 38 No. 4, pp. 673-690.

Zhou, Y. and Xin, T. (2003) "An innovative region in china: Interaction between multinational corporations and local firms in a high-tech cluster in Beijing”, Economic Geography, Vol. 79 No. 2, pp. 129-152. 